University of Chicago Law School

Chicago Unbound

Journal Articles

Faculty Scholarship

1983

\title{
Treatment of Interest on Debtor Obligations in Reorganizations under the Bankruptcy Code
}

Walter J. Blum

Follow this and additional works at: https://chicagounbound.uchicago.edu/journal_articles

Part of the Law Commons

\section{Recommended Citation}

Walter J. Blum, "Treatment of Interest on Debtor Obligations in Reorganizations under the Bankruptcy Code," 50 University of Chicago Law Review 430 (1983).

This Article is brought to you for free and open access by the Faculty Scholarship at Chicago Unbound. It has been accepted for inclusion in Journal Articles by an authorized administrator of Chicago Unbound. For more information, please contact unbound@law.uchicago.edu. 


\title{
Treatment of Interest on Debtor Obligations in Reorganizations Under the Bankruptcy Code
}

\author{
Walter J. Blum $\dagger$
}

After four years of experience with reorganizations under Chapter 11 of the Bankruptcy Reform Act of $1978^{1}$ (the "Code"), we are now in a position to reexamine some questions about interest on obligations of the debtor in bankruptcy reorganizations-questions that are old but emerge in a changed context under the new Code.

Does interest run on unsecured interest-bearing obligations of the debtor after the filing of a petition for reorganization under the Bankruptcy Code?

This question carries a lot of historical baggage. The pre-Code statute did not address it for either secured or unsecured obligations. The courts developed one rule for liquidations and another for reorganizations. They established early that in an ordinary bankruptcy liquidation no interest would run after the filing of the petition, ${ }^{2}$ except that interest at the applicable legal rate would be credited if something of value were left after the allowed principal claims of all creditors had been satisfied in full. ${ }^{3}$ Extrapolating from these rules, the courts later determined that postpetition interest would be allowed at the contract rate in reorganizations in two situations: (1) on secured claims, so long as the value of the collateral covered the enlarged sum, and (2) on unsecured claims,

$\dagger$ Wilson-Dickinson Professor of Law, University of Chicago.

1 Pub. L. No. 95-598, 92 Stat. 2549 (codified as amended as Title 11 of the United States Code (Supp. V 1981)). Chapter 11 is found at 11 U.S.C. \& 1101-1174 (Supp. V 1981). Chapters in the Bankruptcy Code are identified with Arabic numerals; Roman numerals were used for chapter designations in the Bankruptcy Act of 1898, ch. 541, 30 Stat. 544, as amended by the Chandler Act, ch. 575, 52 Stat. 840, 894 (1938), which the Code repealed.

2 Sexton v. Dreyfus (In re Kessler \& Co.), 219 U.S. 339, 344 (1911) (disallowance of postpetition interest in bankruptcy liquidations is a "fundamental principle" founded on 150 years of English practice). (1957).

s In re Inland Gas Corp., 241 F.2d 374, 379-81 (6th Cir.), cert. denied, 355 U.S. 838 
provided that equity owners continued to participate in the business under the reorganization plan."

This rule for unsecured creditors had special significance when there were two or more classes of debt holders whose investments either carried different rates of interest or stood at different levels in the claims hierarchy. If interest payments were denied, classes that held securities with low interest rates or whose obligations were subordinated benefited relative to competing classes holding claims with higher interest rates or that were unsubordinated. In a memorandum submitted to the Supreme Court supporting a petition for a writ of certiorari in Gregory v. Columbia Gas System," the Securities and Exchange Commission ("SEC") vigorously argued $^{\mathfrak{B}}$ against applying the liquidation interest rules to reorganizations involving two levels of unsecured creditors.

The most important, and in our view controlling, difference [between ordinary bankruptcy and reorganizations] is that the debtor's assets in bankruptcy constitute a "dead fund" ... which is to be simply liquidated and divided among the creditors. The assets are normally unproductive during the delay incident to liquidation, and it is perhaps not unreasonable to require the burden of delay to be borne equally by all the creditors by not allowing interest to any. If interest were allowed, the delay would simply change the distribution of the fund without increasing its size. In reorganization, however, the assets which would in bankruptcy have been distributed outright to the senior creditors are retained by the trustee and used to continue the business in operation during the reorganization. Profits earned during that operation will be available for other creditors and the losses, if any, must be borne by the senior creditors, all of whose claims might have been satisfied by an immediate liquidation of the

' City of New York v. Saper, 336 U.S. 328, 330 n.7 (1949); Ticonic Nat'l Bank v. Sprague, 303 U.S. 406, 413 (1938); Memorandum for the Securities and Exchange Commission at 12, Gregory v. Columbia Gas Sys., Inc., 359 U.S. 979 (1959), denying cert. to In re Inland Gas Corp., 262 F.2d 510 (6th Cir.) [hereinafter cited as SEC Memorandum].

s In re Inland Gas Corp., 262 F.2d 510 (6th Cir.), cert. denied sub nom. Gregory v. Columbia Gas Sys., Inc., 359 U.S. 979 (1959).

- The SEC was a party to the Columbia Gas proceedings pursuant to $\$ 208$ of Chapter $\mathrm{X}$ of the Bankruptcy Act, Chandler Act, ch. 575, 52 Stat. 840, 894 (1938), repealed by Bankruptcy Reform Act of 1978, Pub. L. No. 95-598, § 401(a), 92 Stat. 2549, 2682. Section 208 authorized the SEC to intervene in Chapter $\mathrm{X}$ proceedings as a real party in interest with the right to be heard on all matters arising in the proceeding upon judicial request or upon its own motion with judicial consent. 
business. In this context interest is in no sense a "penalty" for the delay in payment but is simply fair compensation to the senior creditors for the productive use by the estate of the assets owing to them. ${ }^{7}$

The effort of the SEC to revise the rules failed when the Supreme Court denied certiorari in the case. ${ }^{8}$

The new Code moved the law in the opposite direction. The Code does not allow postpetition interest at contract rates for unsecured claimants, ${ }^{8}$ and this principle extends even to situations in which equity owners retain a position in the ongoing enterprise. ${ }^{10}$ The unfairness the SEC perceived in the old rules is magnified by the new regime. During the time a reorganization plan is being worked out, the old shareholders might gain at the expense of debenture holders because the shareholders, without paying interest, in effect are able to use the assets that were funded, directly or indirectly, by issuance of the debentures. This state of affairs might easily encourage the old equity owners to drag out the reorganization proceedings as long as possible. If the enterprise is profitable (after taking account of interest due on adequately secured claims), its value normally will increase, whereas the allowable claims of unsecured creditors remain frozen. As a result, the old equity owners might be in a position to capture for themselves any increase in value attributable to retaining profits in the firm-even when the retained profits are less than the realistic interest costs on the unsecured debt. ${ }^{11}$

TEC Memorandum, supra note 4, at 16-17.

359 U.S. 979 (1959).

- 11 U.S.C. § 502(b)(2) (Supp. V 1981). Section 502(b)(2) disallows claims for interest on unsecured obligations unmatured at the time of petition. Id. The Senate report noted "interest stops accruing at the date of the filing of the petition." S. REP. No. 95-989, 95th Cong., 2d Sess. 63 (1978) [hereinafter cited as SENATE REPORT], reprinted in 1978 U.S. CoDE Cong. \& AD. NEws 5787, 5849. The Code still allows interest on secured obligations, at the contract rate, up to the value of the collateral. 11 U.S.C. $\$ 506(b)$ (Supp. V 1981). The problem of interest on secured claims is discussed in Comment, Compensation for Time Value as Part of Adequate Protection During the Automatic Stay in Bankruptcy, $50 \mathrm{U}$. CHI. L. Rev. 305 (1983).

10 Equity holders may participate in a reorganization with the consent of each class of creditors, provided dissenting members of each class receive liquidation value; if a class of creditors does not consent, equity holders may participate once dissenting classes are compensated in full under the fair and equitable standard. 11 U.S.C. \$ 1129 (Supp. V 1981). See infra notes 20-23 and accompanying text. Because postpetition interest not covered by the value of the collateral is not an allowed claim, equity holders may participate before the payment of postpetition interest.

11 The purpose of reorganizing rather than liquidating in bankruptcy is to allow continued productive use of the debtor's assets. Liquidation disposes of the assets of debtors who cannot profitably continue production as a reorganized entity. Disallowance of interest 
One can only speculate as to why the Code mandates such an unjust outcome. ${ }^{12} \mathrm{~A}$ somewhat complicated answer may be inferred from the Code's standards for deciding whether to confirm reorganization plans. Pre-Code law employed two standards. It applied the "fair and equitable" standard to Chapter X of the old Bankruptcy Act, ${ }^{13}$ which, generally speaking, governed publicly held corporations, ${ }^{14}$ it applied the "best interest of the creditors" test to proceedings under Chapter XI of the Act, ${ }^{18}$ which, again generally speaking, governed corporations without public creditors. ${ }^{16}$ The fair and equitable standard is bottomed on the notion that in a reorganization a higher class of investors, as defined by rights in liquidation, is entitled to be compensated in full before a lower class of investors may be permitted to continue in the enterprise undergoing reorganization. ${ }^{17}$ The best interest of the creditors test is grounded on a different idea: a readjustment plan can be confirmed, even though the superior class is not accorded full compensation, so long as its members receive not less than the amount available to them through a liquidation in bankruptcy. ${ }^{18}$ The new Code emphasizes heavily the best interest of the creditors test in

claims of unsecured creditors in reorganizations may allow equity owners to continue to run a debtor corporation whose revenues do not exceed the total cost of operation, including interest expenses. To the extent that interest claims do not accrue after the filing of a petition in bankruptcy, the reorganized entity might appear profitable, and those profits can inure to the benefit of the stockholders.

12 There is a school of thought that believes the outcome is not unjust because the then interested parties presumably took the result into account in striking the deal at the time the securities were first issued, producing a higher rate of interest on the debentures by virtue of the rule against postpetition interest. Whether or not this reasoning is correct in the case of recent borrowings, it should be noted that the Code rule applies to securities issued before enactment.

12 Chandler Act, ch. 575, $\$$ 221(2), 52 Stat. 840, 883, 897 (1938), repealed by Bankruptcy Reform Act of 1978, Pub. L. No. 95-598, § 401(a), 92 Stat. 2549, 2682.

14 By its terms Chapter $X$ was not the only law applicable to reorganizations of publicly held corporations. Chapter $\mathrm{X}$ included substantive protections, however, that were widely thought necessary when publicly held corporations entered reorganizations. Chapter $\mathrm{X}$ typically was applied to publicly held corporations. See General Stores Corp. v. Shlensky, 350 U.S. 462, 465-67 (1956).

is Chandler Act, ch. 575, § 366, 52 Stat. 840, 905, 911-12 (1938), repealed by Bankruptcy Reform Act of 1978, Pub. L. No. 95-598, § 401(a), 92 Stat. 2549, 2682.

16 In Chapter XI, the debtor remained in control of its property and advanced a plan of reorganization itself, rather than through a trustee. Chandler Act, ch. 575, § 221(2), 52 Stat. 840, 883, 897 (1938), repealed by Bankruptcy Reform Act of 1978, Pub. L. No. 95-598, § 401(a), 92 Stat. 2549, 2682. Chapter XI lacked the substantive protections of Chapter X and typically was applied to privately held corporations. See supra note 14.

17 Consolidated Rock Prods. Co. v. Du Bois, 312 U.S. 510, 527-31 (1941); Case v. Los Angeles Lumber Prods. Co., 308 U.S. 106, 114-19 (1939).

1s Fleischmann \& Devine, Inc. v. Saul Wolfson Dry Goods Co., 299 F. 15, 18-19 (5th Cir. 1924). 
combining it with the fair and equitable standard in setting the level for plan confirmation. ${ }^{19}$

The choice of a standard for confirmation of a plan of reorganization now depends on class approval. Creditors and equity hold.ers are divided by the court into classes, the members of each class having substantially similar claims or interests. ${ }^{20} \mathrm{~A}$ class can either approve or reject the plan. ${ }^{21}$ The reach of the fair and equitable standard is confined to a class of creditors or equity owners that does not approve the plan by the prescribed majority; ${ }^{22}$ dissenters within a class that approves the plan are entitled only to the protection offered by the best interest of the creditors test. ${ }^{23}$ The essence of the Code is to hold out a higher level of protection to a dissenting class than to the dissenting members of a class that accepts a reorganization plan. It is implicitly assumed that the primary protection for an investor is the good judgment of the majority of his class, but the majority will not be permitted to force a dissenter into a position that offers less than the dissenter would receive in an immediate liquidation of the business. ${ }^{24}$

This perspective may well have contributed to the new rule on postpetition interest. A class of debt investors is unlikely to accept a plan that denies it postpetition interest while old equity owners stay in the enterprise. Although postpetition interest is not an allowable claim, ${ }^{28}$ nothing in the Code prevents unsecured creditors from insisting on its inclusion in the package they receive if the old stockholders get something under the plan. The same can be said of creditors in classes at different levels in the priority hierarchy.

10 Reorganizations fall within Chapter 11 of the new Code. 11 U.S.C. \$§ 1101-1174 (Supp. V 1981). The standard for plan confirmation is found in id. § 1129.

${ }^{20} \mathrm{Id}$. $\S 1122$. Different types of equity holders and creditors are segregated into different classes. For example, secured creditors, unsecured creditors, common stockholders, and preferred stockholders will each form at least one separate class. Senior and junior unsecured debt will be divided into separate classes, and because of the unique nature of security interests, each secured creditor may form a separate class.

21 A plan can be approved by class vote. A positive vote representing one-half of the members and two-thirds of the dollar amount of a class is necessary for a class of creditors to approve a plan. Approval by a class of equity holders requires a positive vote representing two-thirds of the class dollar value only. Id. § 1126. A class whose interests are not impaired by a reorganization plan is deemed to have approved the plan. Id. $\S 1126(f)$. See infra notes 35-36 and accompanying text.

22 As long as members of a class junior in priority participate in the reorganized entity, a plan cannot be confirmed over the objection of a dissenting senior class of creditors unless that class is compensated in full. 11 U.S.C. $\$ 1129$ (b) (Supp. V 1981).

2s Id. § 1129(a)(7)(A)(ii).

24 A dissenting creditor is ensured at least the liquidation value protection of the best interest of the creditors test. Id.

${ }^{28}$ Id. See supra note 9. 
Senior debenture holders, for example, are not likely to approve a plan that fails to recognize postpetition interest on their investment while junior debenture holders get something under the plan.

In either of these situations the junior class can, under the Code, seek confirmation of the plan over the objection of the seniors. ${ }^{26}$ It then could be argued that the rejected plan is fair and equitable to the seniors in that their allowable claims, which do not include postpetition interest, are compensated in full. The availability of this approach does buttress the position of the juniors. In practice, however, juniors usually will be well advised to make concessions to seniors in order to obtain class approval and thereby avoid resort to a cram-down proceeding. ${ }^{27}$ The fact is that cram-down disputes often entail a valuation of new paper in the continuing enterprise, ${ }^{28}$ and for that reason alone juniors cannot be assured of a favorable outcome. Thus there is likely to be considerable room for bargaining between senior and junior classes as to postpetition interest on debentures and other unsecured interestbearing obligations. ${ }^{29} \mathrm{~A}$ compromise might be expected to provide seniors with compensation for some portion of the total amount of postpetition interest.

The respective bargaining positions will be slightly different when the contending classes are unsecured creditors on the same rung of the priorities ladder but holding claims that carried interest at different rates. ${ }^{30}$ If, without considering postpetition interest,

26 Upon request, the court may confirm a plan over the objections of a class, provided the plan is fair and equitable, 11 U.S.C. $\$ 1129(\mathrm{~b})$ (Supp. V 1981), and any creditor or creditor's committee may propose such a plan, id. \& 1121(c).

27 The approval of a plan over the objection of a creditor or equity holder is a "cram down." A plan, as noted earlier, can be "crammed down" on a dissenting member of an approving class by meeting the best interest of the creditors test, but a plan can be crammed down on a dissenting class only if the fair and equitable standard is satisfied. See supra notes $22-24$ and accompanying text.

28 Creditors are often given obligations of the reconstituted enterprise, requiring valuation of that enterprise to ensure that the plan meets the requirements of $\S 1129$.

20 The juniors and seniors of course could bargain on the entire package to be given the seniors without ever focusing on postpetition interest. But because postpetition interest can be computed as a separate item, there is a likelihood that it will be isolated in the negotiations.

so This assumes that for voting purposes the two sets of debenture owners would be placed in separate classes. If they were grouped together, the low-interest debenture holders, under some circumstances, might then have enough votes to bring about acceptance of the plan by the single combined class-in which case the fair and equitable standard would not apply. If the single class rejected the plan and the old equity interests sought a cram down, then the omission of postpetition interest at differential rates would not be a ground for refusing to confirm the plan over the class's dissent. Indeed, prescribing such differential interest as part of the plan would violate the statutory rule that, to be eligible for cram 
the plan provides both classes with identical compensation, the lower interest-rate class would be in a strong posture to have the plan crammed down on the higher interest-rate class. In the supposed case there would be no need to place a value on debtor paper to be distributed, inasmuch as the plan compensates the two classes alike for each dollar of claim. The Code renders the only distinction between the classes-postpetition interest-wholly irrelevant, and the lower interest-rate class therefore would have little incentive to concede better treatment to the higher-rate class on the basis of a differential in interest rates.

In relying heavily on majority vote to protect members of a class, the Code, in short, does not adequately deal with the postpetition interest problem. The analysis of the SEC in Gregory $v$. Columbia Gas System merits legislative reconsideration. ${ }^{31}$

II

Is the holder of a secured debtor obligation entitled to interest on interest payments that are in default?

Under pre-Code law this question was not addressed by the governing statute which, as noted, did not deal even with simple postpetition interest. The Supreme Court decided in 1946 in Vanston Bondholders Protective Committee $v$. Green ${ }^{32}$ that clauses in instruments calling for interest on interest in default were unenforceable in bankruptcy if the lower court directed the debtor not to pay interest as due. ${ }^{3 s}$

The obligation to make prompt payment of simple interest coupons was suspended. In fact, both [the debtor] and the receiver were ordered by the court not to pay the coupons on the dates they were, on their face, supposed to have been paid. . . . The extra interest covenant may be deemed added compensation for the creditor or, what is more likely, something like a penalty to induce prompt payment of simple interest. In either event, first mortgage bondholders would have been enriched and subordinate creditors would have suffered a corresponding loss, because of a failure to pay when pay-

down, a plan must not discriminate unfairly. 11 U.S.C. § 1129(b)(1) (Supp. V 1981). A plan unfairly discriminates when dissenting classes of the same priority are treated differently.

s1 See supra notes 5-7 and accompanying text. For a suggested legislative solution, see Fortgang \& King, The 1978 Bankruptcy Code: Some Wrong Policy Decisions, 56 N.Y.U. L. Rev. 1148, 1161-65 (1981).

32329 U.S. 156 (1946).

ss Id. at 165-67. 
ment had been prohibited by a court order entered for the joint benefit of debtor, creditors, and the public. Such a result is not consistent with equitable principles. For legal suspension of an obligation to pay is an adequate reason why no added compensation or penalty should be enforced for failure to pay. ${ }^{34}$

Although nothing in the legislation suggests that Congress intended to change this principle, the Code introduces a new concept that raises a novel question about interest on interest in arrears. Under the Code, creditors in a class will be treated as unimpaired, and consequently deemed to have accepted a plan of reorganization, ${ }^{35}$ if the plan (1) cures any default by the debtor on obligations to them, (2) reinstates the maturity of their claims as it stood before default, (3) compensates them for damages incurred as a result of reasonable reliance on a contractual provision or law that entitles them to receive accelerated payment after occurrence of a default, and (4) does not otherwise alter their rights. ${ }^{36}$ The novel question is, should this prescription be construed to mean that interest on any interest in arrears must be paid in order for the claims of a class to be unimpaired?

The Code itself omits any mention of interest on arrearages, and the legislative history is silent on the subject. One might argue that the statutory language rules out requiring payment of compounding interest: when the statute speaks of providing compensation for damages, it refers only to damages attributable to reasonable reliance on a right of acceleration. ${ }^{37}$ To qualify for compensation, a creditor presumably must show that he suffered damages from engaging in some course of conduct on the assumption that payment of the debt would be accelerated as a result of a default. Yet it is not implausible to interpret the statute as covering interest on an arrearage. Were an acceleration permitted, the creditor would receive payment of the debt and then be in a position to invest those funds at interest and to earn interest on that interest. Everyone who invests in interest-bearing securities, it can be assumed, anticipates being able to engage in such additional investment and hence can be considered to have relied on that opportunity. To ignore the value of a compound interest opportunity is to deny the creditor compensation for damages that go to the very essence of his investment. 
Admittedly this interpretation stretches the statutory language. It nonetheless is in keeping with the informing notion of an. unimpaired claim - which is, in brief, that the creditor's position has not been made worse by virtue of reorganization under the plan.

\section{III}

What rate of interest is to be used in figuring the worth of new obligations of the debtor enterprise that are allocated by a reorganization plan to creditors whose claims are impaired under the arrangement?

The selection of the interest rate has long been a central question in reorganization law. Its importance has been reduced by a feature of the new Code that enables a majority, pursuant to the best interest of the creditors test, to bind an entire class of creditors, including its dissenting members, to a plan that provides the entire class with obligations of the debtor having a value not less than the amount available to them through a liquidation in bankruptcy. ${ }^{38}$ But the question retains its vitality in deciding whether, under the fair and equitable standard, a plan can be crammed down on a dissenting class. In many situations the answer to that question is likely to bear heavily on whether some class will accept or reject a proferred plan.

The Code did not purport to change the essence of the fair and equitable standard by limiting it to cram-down occasions. A dissenting class senior in the hierarchy of liquidation priorities is still entitled to full compensation before a junior class is entitled to participate in the reorganized operation. ${ }^{39}$ The Code, however, incorporated statutory language that is more specific than many older judicial formulations of the full compensation rule. ${ }^{10}$ For convenience in exposition, assume that the compensation to an impaired class is to consist entirely of new and/or modified obligations of the debtor undergoing reorganization. The Code prescribes

ss Id. \& $1129(\mathrm{a})(7)(\mathrm{A})(\mathrm{ii})$.

s9 Id. \$1129(b)(2)(B)(ii), (C)(ii). See Blum, Full Priority and Full Compensation in Corporate Reorganizations, 25 U. CHI. L. REv. 417 (1958).

10 E.g., compare Case v. Los Angeles Lumber Prods. Co., 308 U.S. 106, 116 (1939) (" "any arrangement of the parties by which the subordinate rights and interests of the stockholders are attempted to be secured at the expense of the prior rights of either class of creditors comes within judicial denunciation' " (quoting Louisville Trust Co. v. Louisville, N.A. \& C. Ry., 174 U.S. 674, 684 (1899))) with 11 U.S.C. $\$ 1129(b)(2)(B)(i)$ (Supp. V 1981) (creditor must receive compensation equal to the "allowed amount of such claim"). 
that for a plan to be properly confirmed over the dissent of a secured class, the members of the class must receive new obligations, secured by the old collateral, in a principal sum equal to the amount of the allowed claim and having a present value equal to the worth of the collateral. ${ }^{41}$ For a plan to be properly confirmed over the dissent of an unsecured class, the new paper received must have a value, as of the effective date of the plan, equal to the amount of the allowed claim. ${ }^{42}$ The Code thus spotlights the continued importance, under the fair and equitable standard, of determining the present value of promises by the debtor to make payments in the future.

To determine its present value, a sum due in the future must, of course, be discounted to reflect the interest forgone by the creditor during the period the debtor has use of the funds. ${ }^{43}$ In arm's length negotiations between a potential borrower and potential lender, the interest rate on a loan agreement generally will approximate the rate that the lender could obtain in the market for putting out his funds during an equal time span and at a comparable risk of timely payment of both interest and principal. The interest rate governing the loan is equivalent to the rate at which all future payments under the agreement are discounted by the parties to reach present values. A newly negotiated loan accordingly will always have a present value equal to the amount of the loan. An inquiry into the proper rate for discounting the debtor's promise to pay in the future is therefore necessarily the same as an inquiry into the rate of interest to be associated with the creditor's investment.

As an aid to analysis, one can think of impaired creditor classes in a reorganization as making new forced loans to the debtor entity. If the command of the statute were to be carried out literally, cram down would be authorized only if members of the dissenting class received an allocation of new paper that could be immediately sold to a third party for the allowed amount of their claims. The class, in other words, would be entitled to the equivalent of cash in the form of a promise of future payment.

The courts, however, have rejected a cash equivalency version of full compensation in reorganization proceedings from the very

111 U.S.C. \& 1129(b)(2)(A)(i)(II) (Supp. V 1981).

42 Id. \& $1129(\mathrm{~b})(2)(\mathrm{B})(\mathrm{i})$. This rule is inapplicable when no junior class participates under the plan; in that instance, the plan can be crammed down on a dissenting class of unsecured creditors receiving less than the full value of its claims. Id. $\S 1129(\mathrm{~b})(2)(\mathrm{B})(\mathrm{ii})$.

ts See supra notes 41-42 and accompanying text. 
inception of the doctrine. Using a variety of explanations or rhetoric, the courts generally found that cash equivalency was inconsistent with the basic theory of debtor rehabilitation and would in many instances defeat efforts to effectuate a reorganization. At bottom, they were willing to place a value on an enterprise for reorganization purposes that very likely exceeded the worth that the market might contemporaneously register for it. Reorganization value, the critics observed, seems to reflect the court's judgment about probable market value at some unspecified, but not too distant, future date when various predictions underlying the court's reorganization valuation will have transpired and when the market will have been cleared of the stigma and doubts about the enterprise that arose from the very fact that it had been in need of reorganization.4 The discrepancy between a reorganization valuation and a marketplace valuation has been greatest in respect of the value of an equity position in the ongoing business. But the discrepancy might also reside, although to a lesser extent, in debtor obligations that emerge from the reorganization-with the gap being smallest at the level of the most senior security.

The more explicit statutory language in the Code regarding present value ${ }^{45}$ has opened anew the cash equivalency argument, though it seems certain that most courts will still refuse to go the whole distance. A clear statement to that effect is contained in a bankruptcy court opinion in the reorganization of Nite Lite Inns. ${ }^{46}$ A dissenting creditor class argued that, in accordance with the present value requirement, it "should receive a note in an amount which would allow the creditor to walk across the street to the bank and sell the note for the face value of [its] claim."17 Confronted with testimony that a bank would discount the indebtedness arising out of the reorganization by forty to fifty percent, the court responded:

In the present case the showing that the appropriate discount rate should be 40 to 50 percent is unrealistic in light of current loan practice and the purposes of reorganization under the Bankruptcy Code. The adoption of such a rate would im1981).

4 See Blum, supra note 39, at 417-29.

15 See, e.g., 11 U.S.C. $\S 1129(\mathrm{a})(7),(\mathrm{b})(2)(\mathrm{A})(\mathrm{i})(\mathrm{II}),(\mathrm{b})(2)(\mathrm{B})(\mathrm{i}),(\mathrm{b})(2)(\mathrm{c})(\mathrm{i})$ (Supp. V

to In re Nite Lite Inns, 17 Bankr. 367 (Bankr. S.D. Cal. 1982).

67 Id. at 373. 
pose an artificial and unrealistic burden on any debtor seeking to reorganize. ${ }^{48}$

Once cash equivalency is rejected as the test of present value, courts must then face the challenge of locating a satisfactory alternative. Unfortunately they have gone in several different directions, some clearly unsupportable. It makes no sense to use the contract interest rate of the claim that has been impaired, ${ }^{49}$ inasmuch as that obligation is regarded as accelerated and hence matured by the advent of the bankruptcy proceedings. ${ }^{50}$ Perpetuation of a contract rate that is low under current conditions can be justified if a default is cured, the position of the creditor in the collateral is reinstated, and he is compensated for damages; continuing the rate in the absence of these conditions, however, is obviously unfair to the dissenting creditors. It equally makes no sense to apply the legal rate of interest prescribed by state law. ${ }^{51}$ That rate is always uniform and does not account for the particular risks of nonpayment germane to the credit circumstances that the dissenting class is being required to accept through a cram down. For the same reason, automatic application of any other uniform rate, such as the one the Internal Revenue Service charges on tax obligations owed to it, ${ }^{52}$ is also inappropriate.

Perfection obviously cannot be achieved in this area. The best approach might be to use the Internal Revenue Service rate-which is tied to the prime rate for the preceding halfyear ${ }^{53}$ - as a baseline. The prime rate, speaking generally, is supposed to reflect the rate at which the most credit-worthy borrowers

(s) Id.

6 Bankruptcy courts have used the contract rate, often averaged with other interest rates, as the present value discount rate appropriate in personal bankruptcy cases. See, e.g., In re Klein, 10 Bankr. 657, 661-62 (Bankr. E.D.N.Y. 1981) (averaged state statutory legal rate and contract rate); In re Hyden, 10 Bankr. 21, 28 (Bankr. S.D. Ohio 1980) (averaged contract rate, state statutory legal rate, and "leveling factor of an arbitrary 6\%"); In re Smith, 4 Bankr. 12, 13 (Bankr. E.D.N.Y. 1980) (presumption under 11 U.S.C. $\$ 1325$ that contract rate and discount rate are equal). The considerations relevant to the selection of an interest rate are substantially similar in both corporate reorganizations and personal bankruptcy. In re Nite Lite Inns, 17 Bankr. 367, 372 (Bankr. S.D. Cal. 1982).

so "[B]ankruptcy operates as the acceleration of the principal amount of all claims against the debtor." SENATE RBPoRT, supra note 9, at 63, reprinted in 1978 U.S. CoDE ConG. \& AD. News at 5849.

${ }^{B 1}$ Some courts have used the legal rate. See, e.g., In re Klein, 10 Bankr. 657, 661-62 (Bankr. E.D.N.Y. 1981) (averaged state statutory legal and contract rates); In re Hyden, 10 Bankr. 21, 27-28 (Bankr. S.D. Ohio 1980) (averaged state statutory legal rate with contract rate and arbitrary six percent rate).

s2 I.R.C. $\S 6621$ (West Supp. 1982).

s. Id. 
can obtain funds for relatively short periods. From this baseline the rate could be adjusted upward to reflect the likely higher bor-. rowing costs of companies fairly comparable to the debtor in riskiness but not sharing its handicap of being in reorganization.

Under this suggested approach, the interest rate on the coerced investment will vary from half-year to half-year with fluctuations in the index. No index for short-term loans, however, is a sound baseline for arriving at a fixed rate that is to govern a forced loan for a period of years. If a fixed rate is sought in such circumstances, then the baseline ought to be a broad interest index for loans of a duration roughly equal to that of the forced loan imposed by the plan. Adjustments properly would be made from that measure to reflect the particular level of risk for comparable enterprises not suffering a reorganization handicap. ${ }^{54}$

\section{IV}

How does the rate of interest, or discount, on a new obligation of the debtor bear upon the feasibility of a reorganization plan?ss

The question, taken literally, is perhaps too simple to be useful. The rate of interest standing alone is not meaningful for analysis of feasibility; in every instance, the feasibility of reorganization will depend on the totality and timing of an interest burden calculated at a particular rate. This can be seen in two simple examples. First, a plan that calls for $\$ 2,000,000$ principal amount of debentures carrying a ten percent interest rate is less feasible than a plan calling for half the principal amount of identical duration debentures carrying a twenty percent interest rate. Although each version calls for interest payments of $\$ 200,000$ a year, the principal to be repaid is smaller in the second plan. The other example con-

st This suggestion differs from cash equivalence in that, by estimating the present value of the reorganized debtor's securities by reference to similarly situated corporations, it removes the stigma of bankruptcy from the estimation of the debtor's worth, perhaps leading to a more realistic valuation.

${ }^{B S}$ Feasibility is a requirement for plan confirmation. A court may only confirm a plan if "[c]onfirmation of the plan is not likely to be followed by the liquidation, or the need for further financial reorganization, of the debtor or any successor to the debtor under the plan, unless such liquidation or reorganization is proposed in the plan." 11 U.S.C. § 1129(a)(11) (Supp. V 1981). Feasibility has long been a requirement of reorganization. Section 1129 (a)(11) is a "slight elaboration of the law that has developed in the application of the word 'feasible' in Chapter X of the present Act." SEnATE REPoRT, supra note 9, at 128, reprinted in 1978 U.S. Code Cong. \& AD. News at 5914. See Chandler Act, ch. 575, § 221(2), 52 Stat. 840, 897 (1938) (ch. X), repealed by Bankruptcy Reform Act of 1978, Pub. L. No. 95-598, § 401(a), 92 Stat. 2549, 2682; id. § 366(3), 52 Stat. 840, 912 (ch. XI), repealed by Bankruptcy Reform Act of 1978, Pub. L. No. 95-598, §,401(a), 92 Stat. 2549, 2682. 
cerns two arrangements for repaying a $\$ 1000$, ten-year loan at a specified interest rate. One version requires that interest be paid at the set rate annually; the other prescribes that in lieu of annual cash payments, an equal amount, thereafter compounded at the same set rate, be added annually to the sum due at maturity of the loan. The estimated cash flow of the debtor will determine the feasibility of the two plans. Under both alternatives, the debtor borrows $\$ 1000$ at the fixed rate of interest, but under the balloon-atthe-end alternative, the prescribed interest rate also applies to reinvestment of the annual interest obligations. The balloon-at-theend plan nevertheless may be more feasible if the debtor expects cash to be available only in the later years of the loan period, making annual payments in the early years impracticable at best. ${ }^{58}$

All these largely mechanical observations had already entered into the reorganization literature before enactment of the Code; doubtless they were being taken into account in shaping reorganization plans to clear the feasibility hurdle. Although nothing in the Code alters their force, one statutory change presents a puzzle as to the relationship between interest rates and the feasibility of a plan. The Code, as previously noted, mandates that a plan that calls for future payments by the debtor cannot be crammed down on a dissenting class of secured creditors unless (1) the collateral for the old obligation is carried over to the new promise, (2) the promised payment is for an amount equal to the allowed amount of their claims, and (3) the present value of the promise equals the worth of the collateral. ${ }^{57}$ The Code also provides that an undersecured creditor, with or without recourse to other assets of the debtor, can elect to treat the entire amount of the claim as secured. ${ }^{58}$ The puzzle is whether, if the election is in force and the debtor has but a thin equity in the collateral, any plan can ever be crammed down on a dissenting secured class.

The attempted reorganization of Landmark at Plaza Park, Ltd., ${ }^{59}$ a typical real estate tax shelter limited partnership, neatly illustrates the problem. A nonrecourse first mortgage in the amount of $\$ 2,250,000$ was secured by the real estate; the bank-

36 A debtor might be able to borrow against expected future cash flows, but the interest payments required for such a "gap" loan will tend to impair the feasibility of the plan.

${ }^{87} 11$ U.S.C. \& 1129(b)(2)(A) (Supp. V 1981). See supra note 41 and accompanying text.

se 11 U.S.C. \& 1111(b) (Supp. V 1981). By electing to treat an entire claim as secured, the creditor gains a claim, secured by the property, for the full amount of the obligation, but has no unsecured claim for the excess of the debt over the value of the collateral.

6o In re Landmark at Plaza Park, Ltd., 7 Bankr. 653 (Bankr. D.N.J. 1980). 
ruptcy court accepted a value of $\$ 2,260,000$ for the collateral. ${ }^{60}$ Thus the debtor had $\$ 10,000$ equity in the collateral, assuming that all other creditors were otherwise taken care of satisfactorily. The debtor offered a plan, rejected by the mortgagee, that was built around a new obligation on which payments of principal and interest were deferred for up to three years, with the discount or interest computed at $12.5 \%$ annually. ${ }^{61}$ After finding the interest rate to be too low, the court concluded that a fifteen percent rate would be proper under the circumstances. ${ }^{62}$ The court, however, went on to hold that the plan was not feasible at a fifteen percent interest rate, inasmuch as there was great doubt that the reorganized debtor would be able to make the total balloon payment at the end of the three years. ${ }^{63}$

Close analysis of the Landmark opinion suggests that, when the collateral is the only significant asset of the debtor and the equity of the debtor in the collateral is thin, it may never be possible to satisfy both the feasibility requirement and the requirement that the promise to a dissenting creditor class have a present value equal to the amount of its allowed claim. The value of the collateral presumably is based on discounting expected future net cash inflows from the encumbered asset; the value of the nonrecourse promise of the debtor presumably is based on discounting the future payments undertaken by the debtor. Because the debtor's ability to make good on the promise rests on the ability of the encumbered asset to generate net cash inflows, the identical discount rate would seem appropriate to both present value calculations. ${ }^{64}$

Bo Id. at 654 .

81 Id. at 655. The debtor proposed that no interest would be paid for 15 months and that interest, computed at $12.5 \%$, would be paid in months 16-36. At the end of the third year, the debtor would pay the creditor the face amount of $\$ 2,705,820.31$, equal to the sum of the value of the collateral, unpaid interest from the first 15 months, and interest at $15 \%$ on the unpaid interest. Id.

-2 The court observed that the $12.5 \%$ interest rate was less favorable than the creditor could typically find in the market and hence did not satisfy the statute's requirement that the plan compensate the creditor for the deficiency. The court noted that loans of the type the plan envisaged are generally divided between two lenders. For the combined loan, $75 \%$ should carry an interest rate of $13.5-14 \%$, rates at the high end of the range for first mortgage apartment loans. The remaining $25 \%$ would bear the rate typically charged in the second mortgage market, five points above that level, or $19 \%$. The weighted average of these loans approximated $15 \%$. Id. at 658 .

ss At a 15\% interest rate, the deferred interest and regular interest payments would exceed the predicted net rental income and increase in the value of the property, making future default likely. Id. at 661-63.

os See supra text following note 43. In the situation being discussed, it is assumed that the debtor does not possess unusual entrepreneurial skills that arguably render the encumbered asset more valuable in his than in other hands. 
When virtually all the net cash produced by the collateral is required to satisfy the debtor's obligation under the plan, it is difficult to conceive of how a plan could be feasible under the Code.

Logic might lead to the conclusion that both the feasibility standard and the fairness standard can be met in circumstances of this kind only if the debtor yields a substantial share of the equity in the enterprise to the creditor. This approach, however, is not available for dealing with an impaired and dissenting secured creditor class that, seeking to foreclose on the collateral, is out to defeat confirmation of any plan. The Code expressly provides that, in order to cram down a plan on dissenting secured creditors, any new paper of the debtor must be in the nature of an indebtedness, not an equity interest. ${ }^{* 5}$ The use of a realistic interest rate on such paper, as advocated earlier, may well result in preventing cram down on such a dissenting class in cases of thin debtor equity.

\section{Conclusion}

These comments underscore a pervasive point: so long as cram down in bankruptcy reorganizations rests upon the traditional fair and equitable standard, the selection of appropriate interest or discount rates will continue to play a central role in designing and obtaining confirmation of plans.

es 11 U.S.C. $\$ 1129($ b)(2)(A)(i) (Supp. V 1981) (secured creditors must receive "deferred cash payments" and retain their liens). 